\title{
Elemento detetivesco: aproximações entre Sophie Calle e Walter Benjamin
}

Detective Element: approximations

between Sophie Calle and Walter Benjamin 
RESUMO: O objetivo deste ensaio é analisar o trabalho Suite Vénitienne (I98I), da artista Sophie Calle (I953), e contrapô-lo a alguns mecanismos estéticos de Walter Benjamin (I892-I940), tais como: conceito de experiência, arte de narrar, fotografia como técnica política e modificadora do sujeito, conceito de fragmento e mimese. O texto é resultado de um exercício inicial de reflexão.

PALAVRAS-CHAVE: Walter Benjamin; Sophie Calle; arte contemporânea; fotografia.

ABSTRACT: The objective of this essay is to analyze the work Suite Vénitienne (I98I), by the artist Sophie Calle (I953), and counter it to some aesthetic mechanisms of Walter Benjamin (I892-1940), such as: concept of experience, art of narration, and modifier of the subject, concept of fragment and mimesis. The text is the result of an initial exercise of reflection.

KEYWORDS: Walter Benjamin; Sophie Calle; contemporary art; photography. 
Sophie Calle: artista, escritora, fotógrafa. Francesa. 64 anos.

"sophie": variante francesa de "sofia" do grego "sophía". Sabedoria. A sábia. A santidade, o Verbo na forma feminina.

"calle": espanhol. Espaço urbano linear que permite a circulação de pessoas, veículos, conduções. Conduz. Rua.

Sophie Calle: sabedoria das ruas.

\section{CALLE (S)}

Em i980, Sophie Calle retornou a Paris após uma ausência de sete anos. Não se reconhecia no espaço, nas pessoas, nos lugares. Sentia-se desenraizada (CALLE, 2003, p.85). Como flâneur, vagou sem sentido dentro da trama do espaço público urbano. A tríade alteridade, memória e subjetividade ganhou destaque em sua poética artística, um jogo dual entre público e privado, entre ser e reconhecer, entre arte e vida. Por prazer (ou simplesmente pelo jogo), a artista seguia estranhos pelas ruas: "For the pleasure of following, not because they particulary interested me" (CALLE, 2003, p.2). A perseguição resultou em fotos e anotações sobre roupas, movimentos, modo de andar e os caminhos dos transeuntes. Registros. Etnógrafa do mundo e de si, Calle não buscava, a princípio, um sentido específico em sua pretensa pesquisa de campo. Encontrava-se seduzida pelo vagar e por seus instintos. No entanto, algo mudou durante o inverno parisiense de 
janeiro de I980: ela seguiu um homem por alguns instantes e o perdeu para a multidão poucos minutos depois. No mesmo dia, à noite, foi apresentada ao mesmo homem (CALLE, 2003, p.2). Ele estava de passagem marcada para Veneza. De pronto, ela resolveu segui-lo.

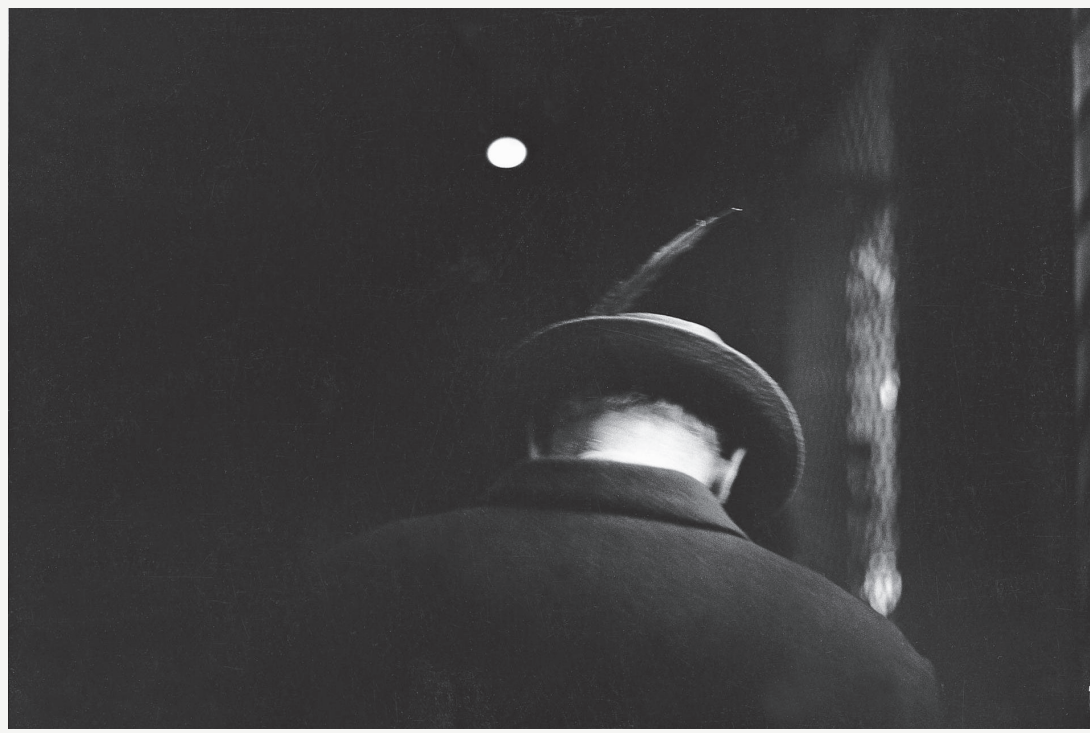

Suite Vénitienne, Sophie Calle, I98I.

O elemento detetivesco é um termo utilizado por Walter Benjamim (I892-1940), oriundo de seu interesse íntimo por romances policiais. O vocábulo aparece pela primeira vez no livro Rua de mão única (I928), composição literária fragmentada e descontínua de temática variada, que continua recorrente até as Passagens (I940), publicado postumamente. Benjamin se vale do elemento detetivesco para pensar os escritos de Edgar Allan Poe (I809-I8949) e Charles Baudelaire (I82I-I867), e os significados do flâneur, dos interiores burgueses, da fotografia. O próprio Benjamin pode ser visto como um detetive: seus textos são fragmentos, constituidores de sentidos múltiplos, pistas que não resultam num pensamento único 
e fechado em si mesmo. Há algo de semelhante entre o escritor moderno e a artista francesa: Sophie Calle utilizou-se do detetivesco como norte de muitas de suas obras, podendo ser considerada invasiva e intrusa em seus trabalhos ou fabricadora de encontros e ressignificações.

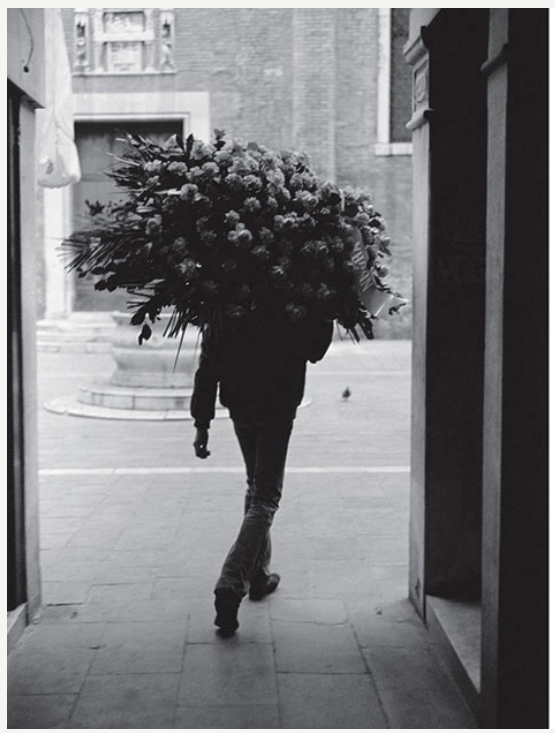

\begin{abstract}
10:00 a.m. I leave the Locanda Montín as a brunette and don my wig in a tiny alleyway nearby. I'll do it this way every day. I don't want to baffle the proprietors. They are already calling me Sophie.

$I$ inquire about Henri $B$. in all the hotels having a first name for a name: Da Bruno, the Leonardo, the San Moise, the Alex ... At lunch time, I look through restaurant windows. I always see the same faces, never his. Tve come to find some consolation in knowing he's not where $\mathrm{I}$ am looking for him. I know where For a few moments, I take a different tack and absentmindedly follow a flower delivery boy - as if he might lead me to him.

2:00 p.m. I settle down in front of the telephone at Anna Lisa G.'s place. The Venice hotel list, not including the Lido, com. prises 181 names divided into several categories: deluxe, first, second, third, and fourth classes; first, second-, and third-class pensiones; and inns. I will call them all in their respective order. Thus I dial the numbers for the hotels Bauer Grünwald, Cipriani, Gritti, Cartton Executive, Europa \& Brittania, Gabrielli, Londra, Luna, Metropole, Monaco \& Grand Canal, Park Hotel, Regina \& Di Roma, Saturnia \& International, Ala, All'Angelo, Al Sole Palace, Austria, Bel Sitio, Bisanzio, Bonvecchiati, Boston, Capri, Carpaccio, Casanova, Cavaletto, Concordia, Continental, Corso, De LAlboro, Do Pozzi, Flora, Giorgione, La Fenice, Montecarlo, Patria Tre Rose, Principe, Residence Palace, San Marco, Terminus, Torino, Union, Universo, Adriatico, All Fava, Antico Panada, Astoria, Ateneo, Atlantide, Basilea, Canal,
\end{abstract}

Suite Vénitienne, Sophie Calle, I98I.

As produções de Calle são autobiográficas ou reconstruções memorialísticas de vivências: envolvem uma alteridade que funciona como contorno, oposição e complementariedade à ideia que ela faz de si mesma. Ao buscar identificação dentro do mar de possibilidades que a vida representa, passa a perseguir no outro sua própria imagem, como um espelho. A narrativa dessa experiência toma forma em diários e relatos fotográficos. Imagem sob imagem, fragmento sob fragmento.

Do jogo à aparência, a artista investigou em Veneza as informações possíveis sobre Henri B., o perseguido conhecido. O esforço foi imenso: polícia, ligações para todos os hotéis da cidade, conversa com outros es- 
tranhos - constituindo um processo obsessivo de busca e registro: o que ele comeu, onde, com quem, o que vestia, a que horas saiu. A perseguição termina quando ocorre o (re)encontro entre os dois e ela regressa a Paris. É a partir desse material etnográfico que Calle organiza o trabalho Suite Vénitienne, composição multifacetada sobre essas duas semanas, composta por imagens e textos. Os fragmentos criam sentidos próprios, para além da própria obra, num movimento de constituição de sentido a partir da arbitrariedade dos elementos. As associações entre texto e imagem na obra de Calle buscam destacar como as experiências vivenciadas pelo homem a partir de um mundo instável, precário e incerto, revelam o escopo para valorar a alegoria como instância explicativa da vida no âmbito estético.

Em Suite Vénitienne, texto e imagem têm caminhos próprios. A sequência escrita é cronológica, marcada pela voz de Calle, como um diário. Possui uma identidade, que é a da artista, formada pela sequência do texto. As imagens são registros que permitem a leitura corrida ou aleatória; são identidades unas que falam por si e podem formar, ou não, uma narrativa. Henri B. ou outros fotografados não têm rostos para serem reconhecíveis. São manchas, cores, formas, representações, que, fundamentadas na memória, conduzem a uma figuração construída a partir de um sujeito (Calle e aquele que observa as fotografias) que busca no objeto (Henri B. ou a própria fotografia) seu outro eu, uma identidade, uma ideia. O olhar gera uma imagem com base na fotografia que é, em si, uma imagem (gênese automática). A colagem de texto e imagem traz Sophie Calle como observadora, como sujeito. No entanto, as imagens sozinhas a excluem da equação de significado, numa dimensão ontológica da fotografia. Ela se dissolve na e pela representação maquínica que está em jogo. Por isso, a foto ganha independência e pode ser lida de maneira autônoma ao texto que a acompanha: o reconhecimento de mim no outro, do fotógrafo no 
fotografado, do sujeito no objeto. Walter Benjamin descreve esse instante (centelha, faísca, flash, acaso), o momento em que a técnica pode dar às suas criações um valor mágico, alegórico:

Apesar de toda a perícia do fotógrafo e de tudo o que existe de planejado em seu comportamento, o observador sente a necessidade irresistível de procurar nessa imagem a pequena centelha do acaso, do aqui e agora, com a qual a realidade chamuscou a imagem, de procurar o lugar imperceptível em que o futuro se aninha ainda hoje em minutos únicos, há muito olhando para trás. A natureza que fala à câmara não é a mesma que fala ao olhar; é outra, especialmente porque substitui um espaço trabalhado conscientemente pelo homem, um espaço que ele percorre inconscientemente. Percebemos, em geral, o movimento de um homem que caminha, ainda que em grandes traços, mas nada percebemos de sua atitude na exata fração de segundo em que ele dá um passo. (BENJAMIN, 1987, p.94)

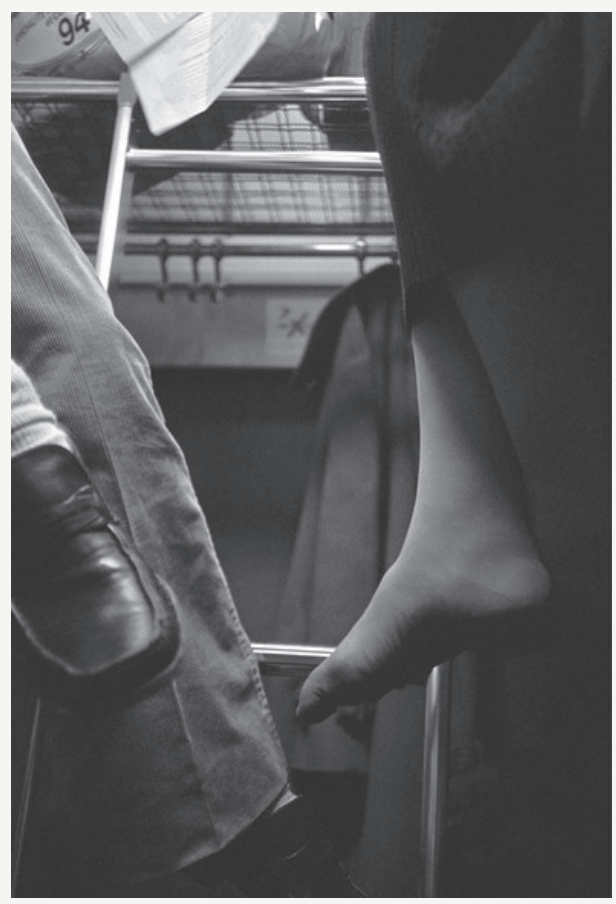

Suite Vénitienne, Sophie Calle, I981. 
O flash, esse segundo da fotografia, é um fragmento retirado da totalidade do contexto da vida. Segundo Peter Burger (2008, p.I40-I47), o conceito de alegoria benjaminiano, importante para se pensar a vanguarda artística, pode ser desmontado da seguinte maneira: a alegoria é essencialmente um fragmento da existência (por isso, não-orgânico, pois não faz mais parte da vida) que, junto a outros fragmentos, ganha um sentido atribuído pelo alegorista, num gesto melancólico, pois esse sentido é privado de vida, entregue ao bel-prazer de seu criador. O material é manipulado, constituído de sentido por uma interpretação do processo de produção e de recepção. O conceito benjaminiano de alegoria permite a separação e a fragmentação dos aspectos ligados à produção e ao efeito estético, e pode ser utilizado para compreender, de acordo com Burger, a obra de arte vanguardista. Para ele, esta também é não-orgânica, como a alegoria: o material é apenas material. Em contraponto, o produtor de uma arte orgânica (clássica, como nomeia Burger) respeita e reconhece o material enquanto portador de um significado, oriundo de "situações concretas de vida”. Para Sophie Calle, semelhante ao flâneur, sujeito espoliado em sua experiência de homem da multidão e de sua incapacidade do olhar $^{\mathrm{I}}$, o fragmento representa tão somente um signo vazio, ao qual ele se acha habilitado a tão somente emprestar significado. Em conformidade com isso, o clássico trata seu material como uma totalidade orgânica; já o vanguardista fragmenta a totalidade.

Para Walter Benjamin, com o advento da modernidade, perde-se uma experiência temporal concreta, gestual e imagética que se oferecia

I Para compreensão sobre a perda da capacidade do olhar no interior da multidão das cidades modernas, ver PALHARES, T. Baudelaire: a experiência da cidade e o declínio da aura. In: Aura: a crise da arte em Walter Benjamin. I.ed. São Paulo: Editora Barracuda,2006, p. 75-IO2 (especificamente, p. 88-90). 
como presença ausente ao indivíduo. Perde-se a experiência autêntica (Erfahrung): "somente a forma de experiência-Erfahrung é capaz de estabelecer uma continuidade, um fluxo em que os fatos exteriores, bem como o passado, deixam de ser alheios, é sobre ela que se erige a tradição" (PALHARES, 2006, p.87). Esta, sendo a essência do que é transmitido de geração em geração, é fundada com base na experiência autêntica, que em si é a comunicação por meio das reminiscências. Seu enfraquecimento, com o abalo desse fluxo através da reincidência da vivência do choque (atitude de consciência e de sobrevivência frente à ofuscante industrialização de grande escala), desestrutura o sistema cultural da experiência de uma sociedade, de um indivíduo. "Benjamin reconhece sua marca (vivência do choque) em todas as configurações dessa sociedade industrial: do lazer ao trabalho, do clique do fotógrafo ao ritmo da montagem do filme" (PALHARES, 2006, p.88). Sophie Calle coloca em xeque essa vivência do choque - consciente de seu papel na multidão, deseja dar um peso, um significado, aos fragmentos da totalidade de sua existência.

Outro conceito pode ser aqui pensado: nos ensaios A doutrina das semelhanças, de I933, e Sobre a faculdade mimética, de i935, Walter Benjamin discute o conceito de mimese enquanto uma semelhança não física, um instante temporal em que há um aparecer, marcado pelo desaparecimento instantâneo, mas que permite uma experiência de tempo imediata, de reciprocidade entre o sujeito e objeto. Esta semelhança é, para além das dimensões de espaço e imagem, temporal (onde o vazio entre o mesmo e o outro está associado ao aparecer) e da ordem do acaso, imprimindo uma liberdade ao estado de semelhança não física, associando à atividade do jogo (BURGER, 2008, p.I43). 


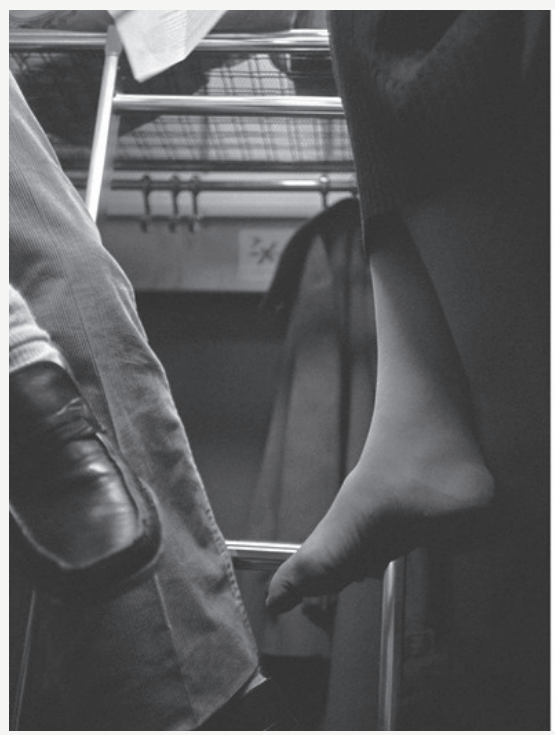

10:00 pm. Gare de Lyon. Platform H. Venice boanding area. My father accompanies me to the platform. He waves his hand.

In my suitcase: a make-up kit so I can disguise myself; a blond, bobbed wig; hats, veils, gloves, sunglasses; a Leica and a Squintar photos without aiming at the subject).

I photograph the occupants of the other berths and then go to sleep.

Tomorrow I will see Venice for the first time.

Suite Vénitienne, Sophie Calle, I98I.

O jogo é ordenado: Sophie Calle, para não ser reconhecida por Henri B., disfarça-se, torna-se outra. Primeiramente, ela persegue a vida de alguém como se esta fosse aleatória; não se sabe, a princípio, quem é Henri B., sua profissão, seus gostos, nada. Absolutamente nada. Ele é alguém, um passante aleatório na multidão. Segundo, cria-se um distanciamento de si para perseguir o outro. O jogo mimético está estabelecido e tem início sua dualidade benjaminiana, da aparência e do jogo, do semelhante². A poética de Calle se alimenta dessa trama intersubjetiva, podendo despertar essa ressonância do outro em seu processo de subjetivação e vice-versa. Em seus relatos, há o desejo de identificação com Henri B.: "I see myself at the labyrinth's gate, ready to get lost in the city and in this story. Submissive" (CALLE, I988, p.6). A figura de subjetividade resultante desse processo

2 Para mais, ver: CAIMI, C. A aparência e o jogo na arte e na literatura. In: CAIMI; OLIVEIRA. (Orgs). Sobre alguns temas em Walter Benjamin. Porto Alegre: Editora UniRitter, 2015, p. I47-I63. 
de mistura de tempos, sujeitos e lugares, trabalha o movimento pendular entre memória e esquecimento, entre história e narrativa.

A narrativa enquanto memória do lugar, o retornar ao passado, enquanto tradição, às origens, é estranha ao homem moderno. A existência individual nas grandes metrópoles não dá brechas para a constituição da experiência. Walter Benjamin desenvolveu uma teoria da narração que abarca a experiência e a memória, articulando no mesmo plano as condições individuais e coletivas de transmissibilidade da narração. Calle intercala em suas imagens descrições e pensamentos íntimos, reais ou não, verídicos ou não: reconstrução da narrativa por meio de uma intimidade construída (e qual não é?), numa proposta autobiográfica que conjuga poesia, memoria e comentário - "Nem tudo na vida é modelar, mas tudo é exemplar" (BENJAMIN, 1987, p.36). Analisando Marcel Proust para pensar o processo narrativo e como ele abarca as questões da modernidade, quais sejam, a ausência da tradição e da experiência e a fragmentação da vivência, Benjamin diz:

Sabemos que Proust não descreveu em sua obra uma vida como ela de fato foi, e sim uma vida lembrada por quem a viveu (...). Pois o importante, para o autor que rememora, não é o que ele viveu, mas o tecido de sua rememoração, o trabalho de Penélope da reminiscência. Ou seria preferível falar do trabalho de Penélope do esquecimento? A memória involuntária, de Proust, não está mais próxima do esquecimento que daquilo que em geral chamamos de reminiscência? Não seria esse trabalho de rememoração espontânea, em que a recordação é a trama e o esquecimento a urdidura, oposto do trabalho de Penélope, mais que sua cópia? (BENJAMIN, I987, p.36) 


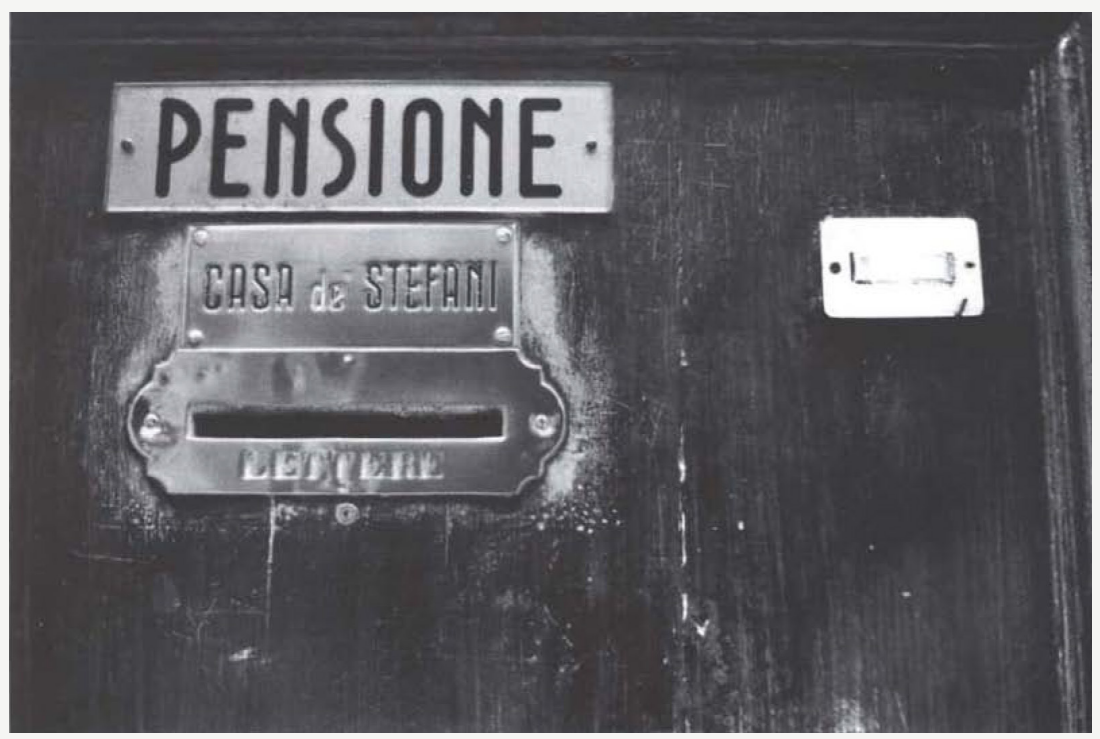

Suite Vénitienne, Sophie Calle, I98I.

No final de todos os dias, Sophie Calle fazia questão de anotar a hora a que ia para cama ou retornava à pensão onde estava hospedada - como um desfecho diário, rotineiro, importante para o esquecimento e recomeçar do dia seguinte, do zero, novamente, como Penélope. Calle tece a perseguição e a desfaz para tecê-la no dia seguinte: "Did she simply wish to assume his destiny, or that he assume hers? This game, as any other game, had its basic rule: Nothing was to happen, not one event that might establish any contact or relationship between them. This is the price of seduction". (BAUDRILLARD, I988, p.78-79) 

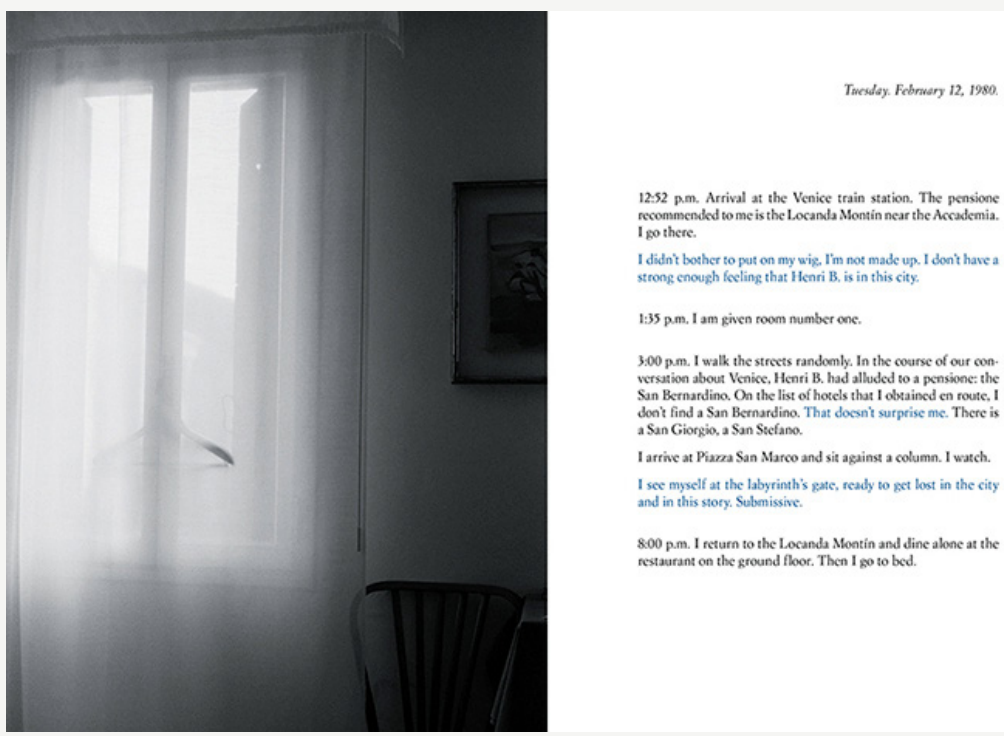

$3.00 \mathrm{pm}$. I walk the streets randomly. In the course of our conversation about Venice, Henri B. had alluded to a pensione: the San Bernardino. On the list of hotels that I obtained en route, I don't find a San Bernardino. That docon't surprise me. There is a San Giorgio, a San Stefano.

I artive at Piama San Marco and sit against a column. I watch. I see myself at the labyrinth's gate, ready to get lost in the city and in this stoty. Submissive.

$8.00 \mathrm{p} . \mathrm{m}$. I return to the Locanda Montin and dine alone at the restaurant on the ground floot. Then I go to bed.

Suite Vénitienne, Sophie Calle, I98I.

Segundo Benjamin, cada momento da experiência se plasma diferentemente no decorrer das transformações estruturais da humanidade, seja nas esferas pública e privada, na percepção do tempo e nos meios de produção material. Como um romance, Calle narra sua experiência como uma interprete de si mesma e daquele que observa as fotos e os textos: nos registros materiais, há o reconhecimento de si; o anônimo se encontra no sujeito observador e vice-versa. Somos todos Henri B. Somos todos Sophie Calle. A experiência não é mais articulada na memória coletiva; é pessoal, individual - é rememorada para interpretar esse passado e salvá-lo do vazio da existência. As lacunas da memória são entrecortadas por impressões não assimiladas na consciência e que voltam à tona na rememoração. 


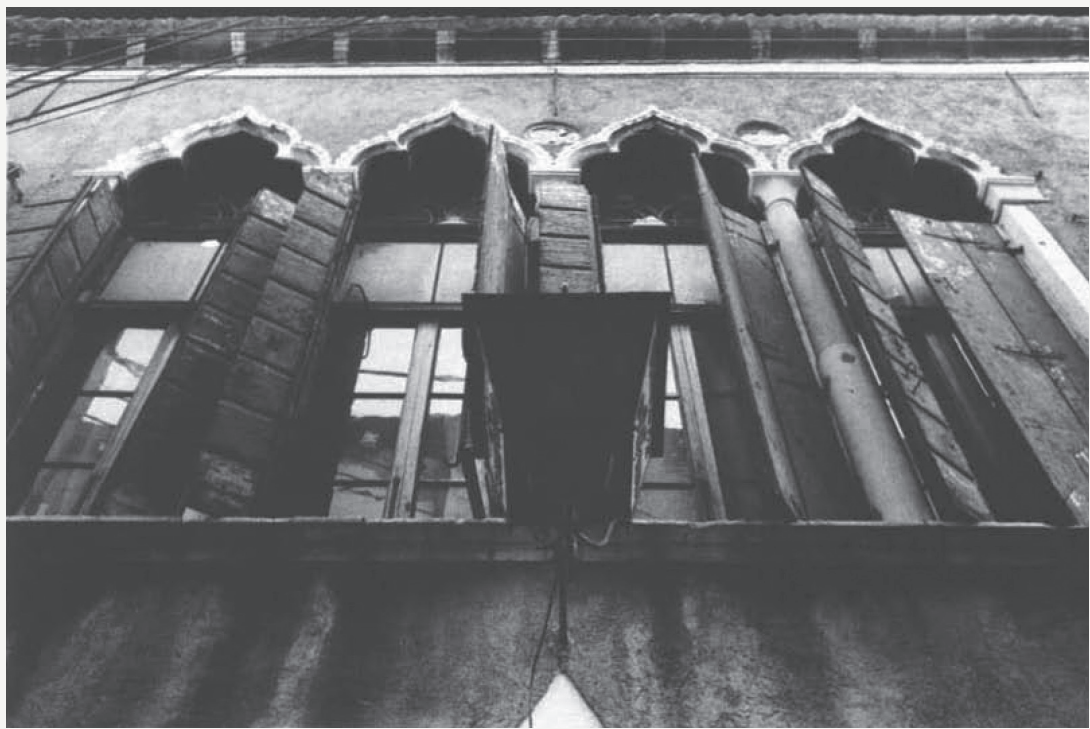

Suite Vénitienne, Sophie Calle, I98I.

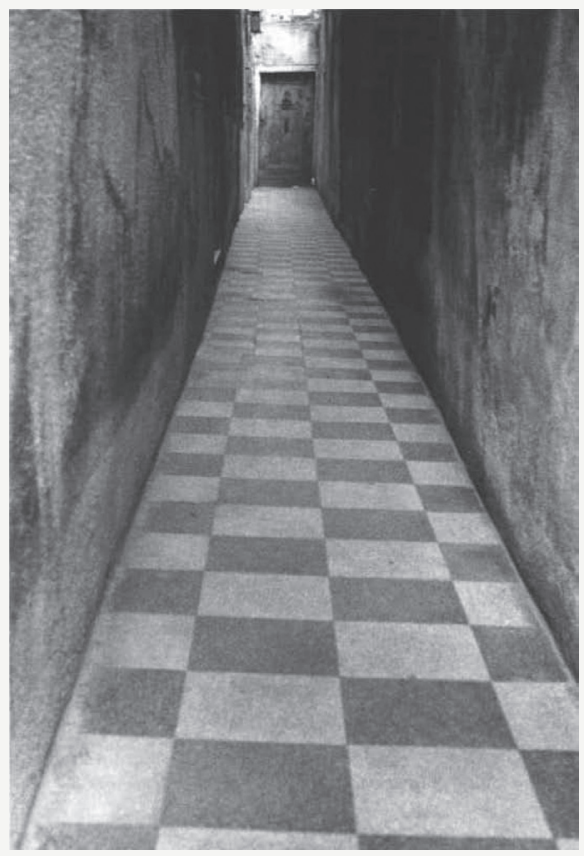

Suite Vénitienne, Sophie Calle, I98I. 
Como Baudelaire, Calle flana pelas calles de Veneza, pelos becos e vielas, atrás de seu perseguido. Baudelaire representa a existência do artista numa época em que a vida do espírito foi reduzida ao consumo de mercadorias, os bens culturais. Henri B. não é turista em Veneza; é um anônimo, apesar de sua teia de relações pessoais e lugares que frequenta (ele visita um antiquário, conhece a cidade, sua esposa o acompanha na viagem, conversa intimamente com pessoas, vai e retorna algumas vezes durante o período). Mas são nas horas em que está sozinho, caminhando, que Sophie Calle se reconhece, que o flâneur de Baudelaire aparece: um anônimo caminhante. Não à toa, um de seus lugares preferidos é o cemitério: os mortos não falam, apenas nos fazem lembrar de que somos todos anônimos; imortais na memória e inexistentes materialmente.

A sociedade moderna de Walter Benjamin apropria-se fantasmaticamente dos meios de produção social, cuja forma se manifesta sobretudo na transferência ilícita de conceitos do domínio da arte tradicional para os novos meios, além da repetição fantasmagórica de um passado que retorna reprimido. Baudelaire percebe a tensão do tempo moderno, do tédio das massas, do tempo linear e mecânico; o passado, a memória, as tradições limitam-se em seus escritos com o novo. Ele reconheceu o fracasso da experiência autêntica pois viu na rememoração os elementos de culto impossíveis na grande cidade, vivenciado nos espaços de memória, nos feriados, nos dias festivos. 


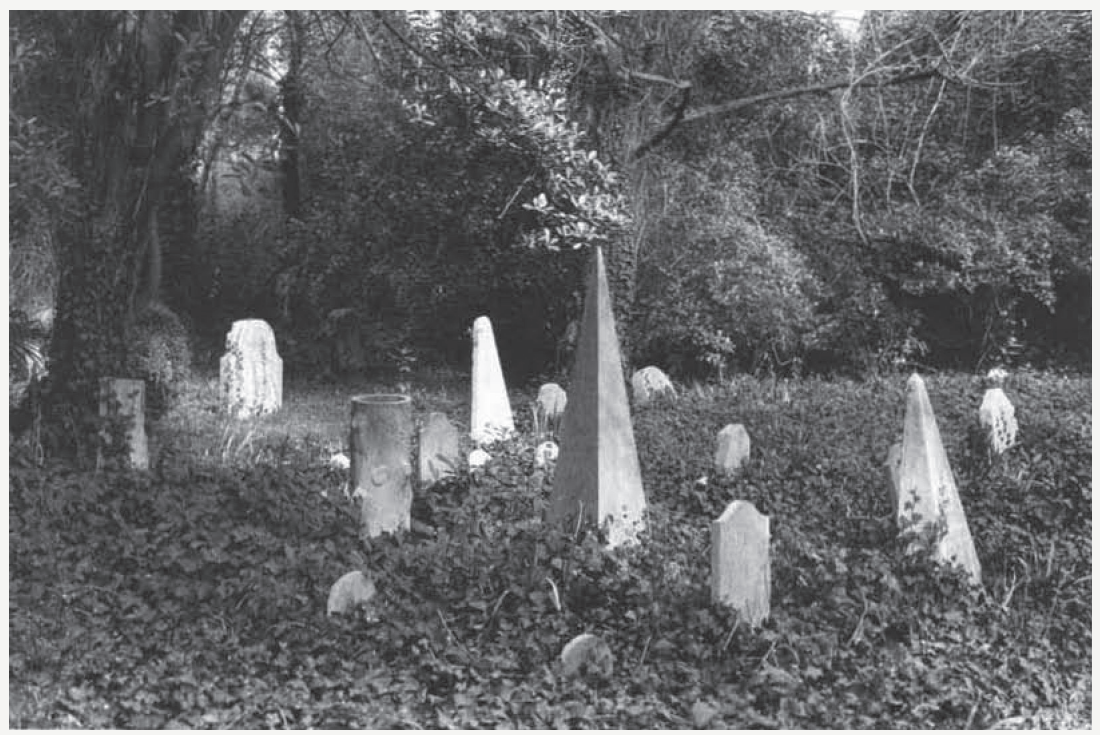

Suite Vénitienne, Sophie Calle, I98I.

Para Walter Benjamin, somente Baudelaire, em sua posição intermediária de flâneur, "por meio da recordação da experiência que sabia estar em vias de extinção" (PALHARES, 2006, p.9o), poderia compreender a verdadeira derrocada do homem moderno: o fim da articulação comunicativa, por meio da experiência autêntica, entre o sujeito e o mundo, onde as coisas que o sujeito vê retribuem o mesmo olhar. Essa articulação fornece ao indivíduo uma autoimagem que é social e histórica. Sophie Calle estabelece essa experiência articulando os signos de seu tempo e do espaço. Seus trabalhos, podemos pensar, são atualizações das experiências realizadas no espaço urbano do final do século XIX e início do XX, indo até aos artistas surrealistas (ou até mesmo aos situacionistas, dos anos I950). A errância era fundamental para perder-se na cidade e apaixonar-se pelo instante ou pelo outro que passa, e logo retornar ao tédio urbano, como um suspiro. 


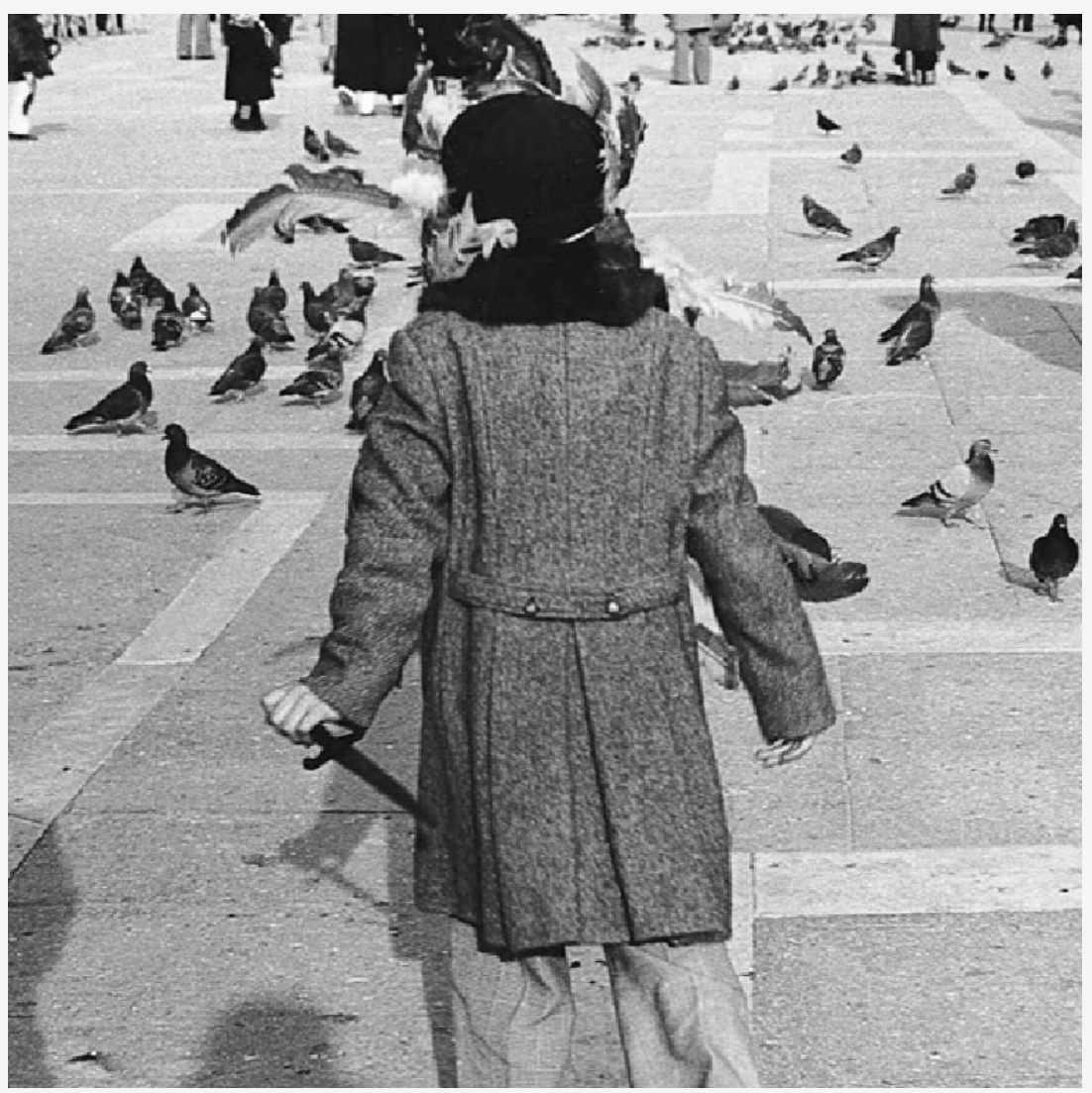

Suite Vénitienne, Sophie Calle, I98I.

\section{A uma passante}

A rua em torno era um frenético alarido.

Toda de luto, alta e sutil, dor majestosa,

Uma mulher passou, com sua mão suntuosa

Erguendo e sacudindo a barra do vestido.

Pernas de estátua, era-lhe a imagem nobre e fina.

Qual bizarro basbaque, afoito eu lhe bebia

No olhar, céu lívido onde aflora a ventania,

A doçura que envolve e o prazer que assassina. 
Que luz... e a noite após! - Efêmera beldade

Cujos olhos me fazem nascer outra vez,

Não mais hei de te ver senão na eternidade?

Longe daqui! tarde demais! "nunca" talvez!

Pois de ti já me fui, de mim tu já fugiste,

Tu que eu teria amado, ó tu que bem o viste!

(BAUDELAIRE, I985, p.36I)

O inconsciente regeria os encontros fortuitos com os objetos, lugares e pessoas, em uma mescla de real e imaginário, de sedução do eu e o do outro. A reciprocidade entre a ausência do seguido e do seguidor registrado nas imagens (foto e texto) de Calle não são a lembrança de uma presença, mas as marcas de uma ausência dupla: do objeto e do olho: "These are not souvenir snapshots of a presence, but rather shots of an absence, the absence of the followed, that of the follower, that of their reciprocal absence" (BAUDRILLARD, i988, p. 78-79).

O destino de Sophie Calle por Veneza era ditado por Henri B., sem o saber, fazendo experimentar uma outra Veneza, ocorrendo uma desorientação psíquica, possibilitadora de uma nova experiência de vida, de um novo mapa interno. Ocorre o choque, a mudança que Benjamin julga necessária à vida moderna ao permitir ser conduzido pelo outro, em meio a uma solidão solidária, comum aos ambientes urbanos. 


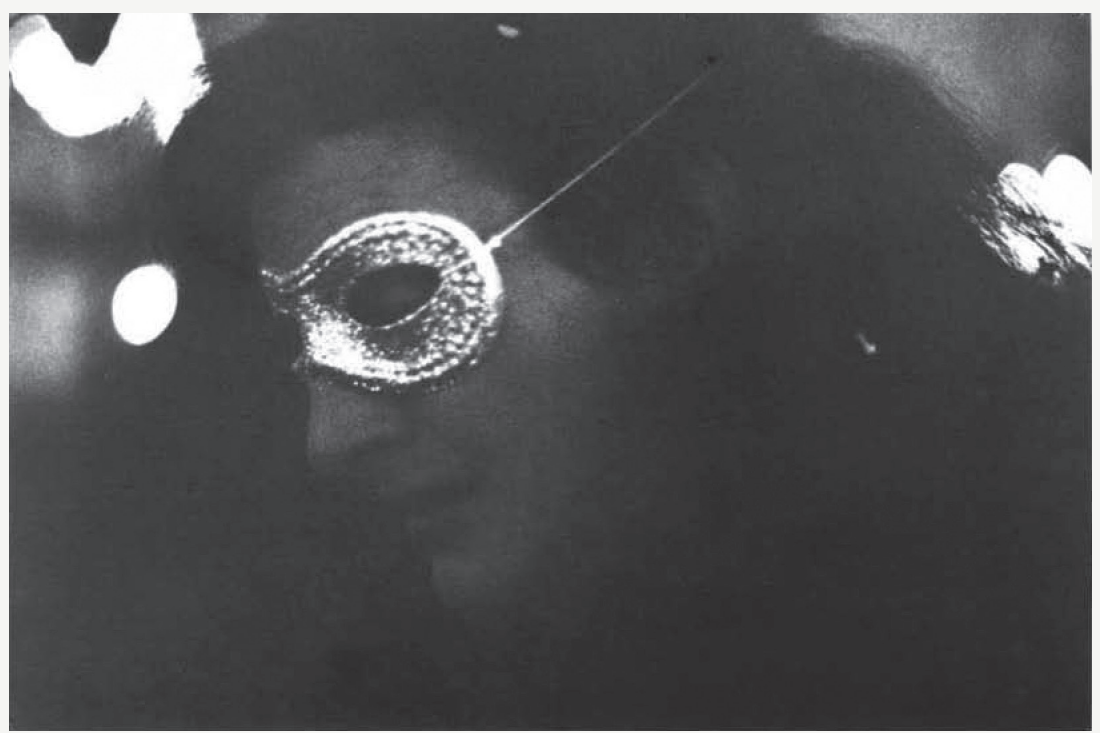

Suite Vénitienne, Sophie Calle, I98I.

To follow the other is to take charge of his itinerary; it is to watch over his life without him knowing it. It is to play the mytical role of the shadow, which, traditionally, follows you and protects you from the sun - the man without a shadow is exposed to the violence of a life without mediation - it is to relieve him of that existencial burden, the responsability for his own life. Simultaneously, she who follows is herself relieved of responsability for her own life as she follows blindly in the footsteps of the other. Again, a wonderful reciprocity exists

In the cancellation of each existence, in the cancellation of each subject's tenuous positions as a subject. Following the other, one replaces him, exchanges lives, passions, wills, transforms oneself in the other's stead. It is perhaps the only way man can finally fulfill himself. An ironic way but all the more certain.(BAUDRILLARD, I988, p. 82-83)

De modo geral, um dos grandes segredos do trabalho de Sophie Calle é a capacidade de comunicação e atribuição de funções a terceiros. Ela quase nunca depara com recusas ou indiferença aos seus pedidos. Com di- 
ficuldades de encontrar Henri B., articula uma rede de ajudantes, dentro de uma ordem simbólica da obrigação: ela conta sua história e pede ajuda. Sempre a recebe de estranhos, nunca de autoridades (por exemplo, a polícia). Uma rede solidária envolve a perseguição à Henri B., e tudo começa, entre Calle e o terceiro, com uma narrativa. Sophie Calle é um narrador/ detetive semelhante ao de Walter Benjamin: o narrador é tanto aquele que conta sobre algo distante, a partir de suas experiências (como as viagens), como o que permanece em casa e conta a partir do conhecimento da história e tradição. No entanto, Calle refaz sua própria história por meio da possibilidade do acaso. O desconhecido caminho pelo qual a artista segue permite-lhe tramar novos olhares para o banal: interessar-se por alguém e imaginar sua vida, sua história, é o hábito comum daquele que observa. Épocas diferentes as de Benjamin e Calle: por um lado, a modernidade em que o homem passa a se reconhecer como um ser autônomo, autossuficiente e universal. Pela razão, atua sobre a natureza e a sociedade. Sophie Calle, por outro lado, experimenta a crise da razão, a dissolução da lógica e da garantia de possibilidade de compreensão do mundo por esquemas totalizantes. Perde-se no instinto e, ao mesmo tempo, dialoga com ele, racionalizando-o, interpretando-o, deixando fluir.

A artista narra o que está acontecendo, reconstituindo o espaço social da narração (Veneza e todos os infortúnios decorrentes da ação) e a tradição (o ato de sedução em si, o desejo do encontro, o amor, a sedução e a espera). A teoria da narração circunscrita por Benjamin parte da figura do narrador ligada aos ofícios antigos e medievais, à transmissão, via oralidade, da tradição e da experiência (BENJAMIN, 1987, p.197-22I). Esse ritual confere grandeza às narrativas escritas, desde que elas mantenham os traços orais. Os registros de Calle (suas fotografias, o diário, a conversa com os estranhos, as caminhadas, enfim) não são narrativas grandiosas 
ou eloquentes. Pelo contrário: são silenciosas, simples, familiares. Após o contato com a história contada por Calle em Suite Vénitienne, a memória do espectador/leitor/do outro permanece ativa. Ele se reconhece na artista, na paixão da perseguição e na ânsia do encontro. A narração prescinde de explicações, deixando ao interlocutor a liberdade de interpretação: o espectador/terceiro leitor de Sophie Calle, interessado em se apropriar das imagens/história/perseguição de Henri B., renuncia às sutilezas psicológicas e racionais da ação a ponto de se tornar mais fácil a ele memorizar os fatos, participar do processo e transmiti-los. O esquecer-se de si mesmo continua, como no trabalho artesanal e na demora do feitio, e está no tempo que leva a jornada de Calle.

A outra força de Suite Vénitienne vem da potência do afeto estabelecida por Calle com os sujeitos. A efemeridade das relações amorosas que podemos encontrar a partir de um encontro fortuito é base para o trabalho. Cegamente, cedemos ao outro, como nas paixões fulminantes, e aos seus caprichos e desejos. O acaso permite o reencontro com aquele homem, mas a razão e o distanciamento de si e do outro, permanecem.

I think about him and that phrase by Proust: "To think that I've wasted years of my life, that I wanted to die and I had my greatest love, for a woman whom I did not care for, who was not my type".

I must not forget that I don't have any amorous feelings toward Henri B. The impatience with I await his arrival, the fear of that encounter, these symptoms aren't really a part of me. (BAUDRILLARD, I988, p.20-2I)

O acaso permite o reencontro com aquele homem, é o disparador da perseguição. Henri B. torna-se o espetáculo, e tudo o que gira em torno desse microcosmo é do interesse do sujeito, até mesmo uma inesperada surpresa: a esposa de Henri B. o acompanha, principalmente pelos 
passeios. Registros dos dois, ora juntos, ora separados, mudam o teor do trabalho: "The other source of passion, which is in a way the opposite of challenge, is the secret wish to submit oneself blindly to the other's desire (...) Blessed, beneficent is anything that takes us to the unwilled, into dreamlike disengagement, Rimbaud would say, from out own life"(BAUDRILLARD, I988, p.8I).

Em paralelo com os surrealistas, pode-se pensar no acaso objetivo de André Breton, em Nadja - um encontro que, objetivamente, ocorre ao acaso e que, de fato, parece não ter sido um acaso, ou seja, parece significar alguma coisa. Os fatos e os objetos nos acenam, e algo surge como querendo ser um signo, sem que saibamos realmente de que signo se trata. Em fragmentos, como a própria vida, o acaso do afeto se estabelece e, assim, cria-se um desejo, um aquém, para além da razão, que permanece no instante da chama. No instante do flash. Nas particularidades dos sujeitos, tal como faz o detetive. Num fluxo contínuo, tal qual o cinema, em que as imagens ganham vida para além da matéria. A fotografia se beneficia de uma transferência de realidade da coisa para sua reprodução, sendo assim uma emanação do referente.

Como se vê, passamos de um efeito de realismo (da ordem da estética da mimese) a um efeito de realidade (da ordem da fenomenologia do Real). Se o primeiro encara os dados em termos de semelhança, o segundo o faz em termos de existência e de essência. E, paradoxalmente, o deslocamento que assim se opera permite concluir pertinente: a imagem fotográfica vale aí como traço de um "isto foi" (Barthes), como uma espécie de forma do mundo visível (Bazin), antes de ser reprodução fiel das aparências. A lógica do vestígio (o índice, de acordo com Peirce) prevalece sobre a mimese (o ícone). Assim, vemos que o ganho de analogia da imagem fotográfica é algo, no mínimo, relativo, e o deslizamento do realismo à realidade acaba por reduzir a importância do critério mimético. (DUBOIS, 2004, p.5I) 
Nesse ponto do trabalho, em que Calle encontra Henri B. e o persegue junto a sua esposa pelas ruelas de Veneza, o objeto ganha realidade para além da imagem. Para além de um único registro, há sequências do "passeio" pela cidade. Há o registro do movimento: das fotografias/registro do estranho, como semelhante mimético (alguém em deslocamento como eu, o fotógrafo, espectador), para a realidade, a existência e a essência, numa ordem da fenomenologia do Real. O objeto em si ganha mais importância, pois deixa de ser uma imagem e ganha vida, ganha realidade. O cinema permite o realismo do tempo (mesmo, neste caso, com as imagens estáticas, pois há o pressuposto do movimento pela narrativa ativa de Calle); a mimese fílmica expõe o mundo em sua duração e movimentos.
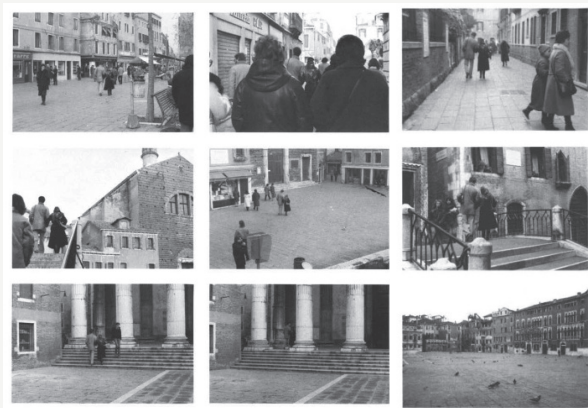
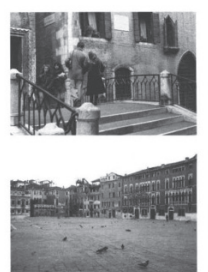
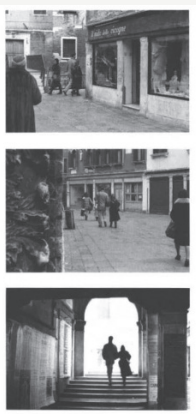
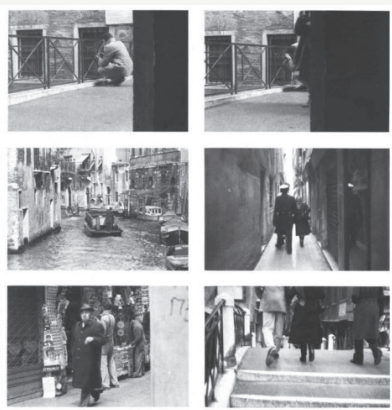

Suite Vénitienne, Sophie Calle, I98I.

A concepção benjaminiana de cinema (vinda da experiência com o cinema de atrações, as vistas, seu público histórico específico e, com seu contraponto, o cinema brechtiano) é oriunda de sua concepção de meios de comunicação de massas a partir da reprodutibilidade técnica. Deixando de lado os limites de sua interpretação de Karl Marx, é importante salientar que ele considera o capitalismo criador das sementes de sua própria destruição, já que possibilita as condições para o surgimento 
de técnicas e mecanismos de questionamento. As mudanças no modo de produção demoram para chegar à superestrutura, já que esta tem um desenvolvimento lento. A reprodutibilidade técnica, por sua vez, seria uma ferramenta crítica para a mudança de percepção do homem moderno, ainda estagnado nas concepções estéticas burguesas do século XIX. O que se atrofia na era da reprodutibilidade técnica da obra de arte é sua aura, num processo sintomático e muito além do campo da arte. A reprodução destaca o objeto reproduzido do domínio da tradição, da autenticidade, da unicidade.

A sequência de imagens de Henri B. e da esposa revelam um deslocamento de importância do objeto: antes, a ausência de Henri B. tinha uma magnitude da espera, do desejo, do suspiro. Por isso, era apenas um registro de cada vez. Um simples registro que abraça a potência daquela espera e perseguição. A partir do momento em que sua presença se torna constante, quase banal, e duplicada pela presença da esposa, o desejo foi destruído. A espera não existe mais. Aquele momento único, o afã, a ausência pela ausência, desaparece. As imagens se sobrepõem e uma sequência cinematográfica surge, formando uma cena estabelecida pelo cinema: um casal passeando por Veneza, de mãos dadas, no inverno. É nesse momento, entretanto, que o quadro pode ser visto como crítica, como questionador, como choque. Não mais as imagens são fotografias de Calle sobre si mesma, sobre sua busca pelo reconhecimento próprio na ausência do outro; agora, é o espectador que se vê no casal comum caminhando pelas ruas de Veneza a partir de uma identificação com a imagem, num paralelismo com a imagem cinematográfica. A luz do projetor do cinema mascara nosso corpo, como uma energia mística, e leva-nos à identificação com a imagem em movimento. 


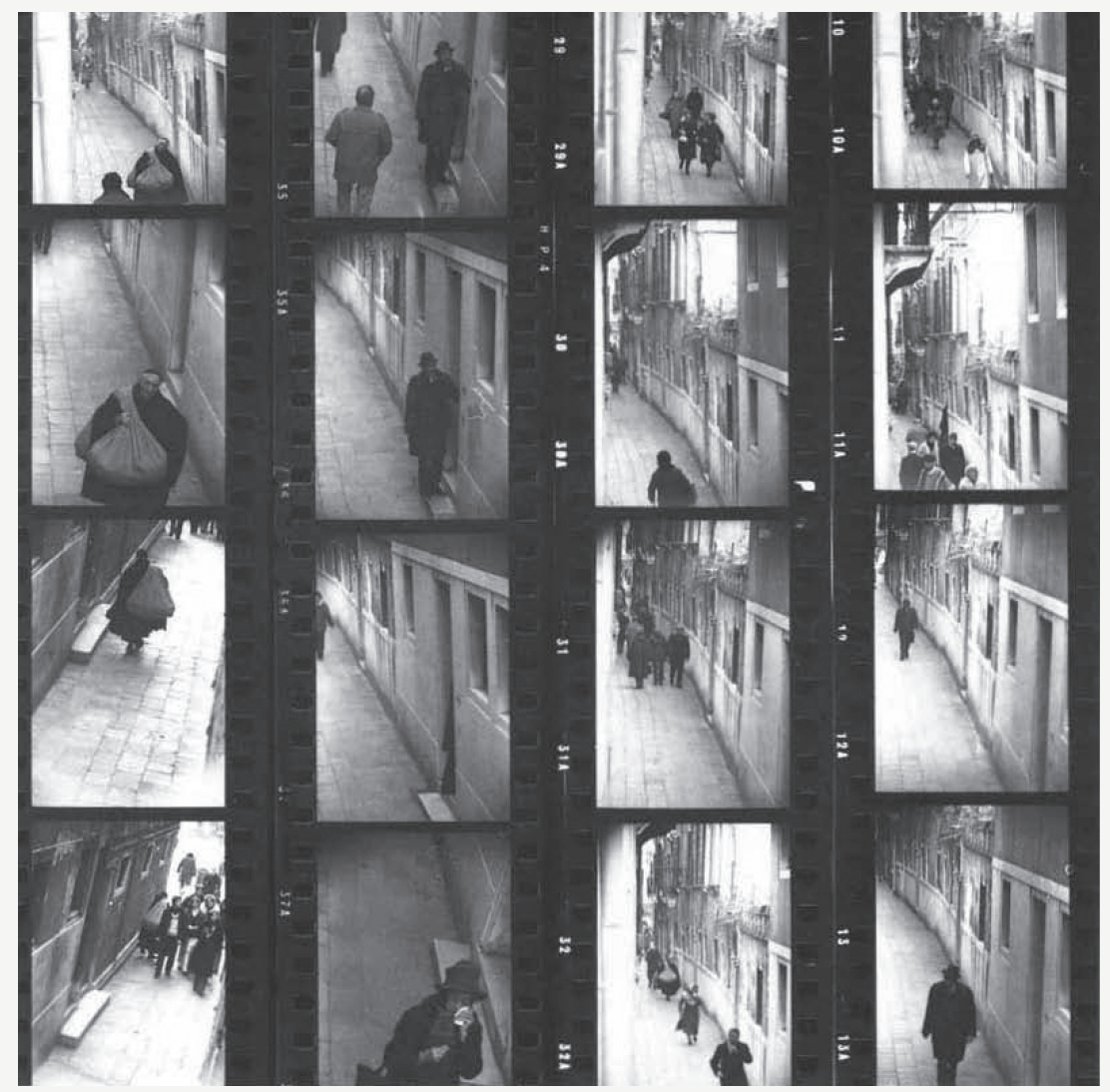

Suite Vénitienne, Sophie Calle, I98I.

(...) um aspecto curioso desta fase cinematográfica: se o maquinismo ganha nela um estrato a mais no sistema geral das imagens, isto não resulta numa perda acentuada de aura ou artisticidade. Pelo contrário, podemos mesmo considerar que a maquinaria cinematográfica é em seu conjunto produtora de imaginário (daí provavelmente a singularidade exemplar e a força incomparável do cinema). Sua força reside não apenas na dimensão tecnológica, mas primeiro e sobretudo na simbólica: o cinema é tanto uma maquinação (uma máquina de pensamento) quanto uma maquinaria, tanto uma experiência psíquica quanto um fenômeno físico-perceptivo. Sua maquinaria é não só produtora de imagens como também geradora de afetos, e dotada de um fantástico poder sobre o imaginário dos espectadores. A máquina do cinema reintroduz as- 
sim o Sujeito na imagem, mas desta vez do lado do espectador e do seu investimento imaginário, não do lado da assinatura do artista. Portanto, tanto um quanto o outro constituem a imagem, que só é digna deste nome por trazer em sua espessura uma potência de sensação, de emoção ou de inteligibilidade, que vêm de sua relação com uma exterioridade (o Sujeito, o Real, o Outro). (DUBOIS, 2004, p.44-45
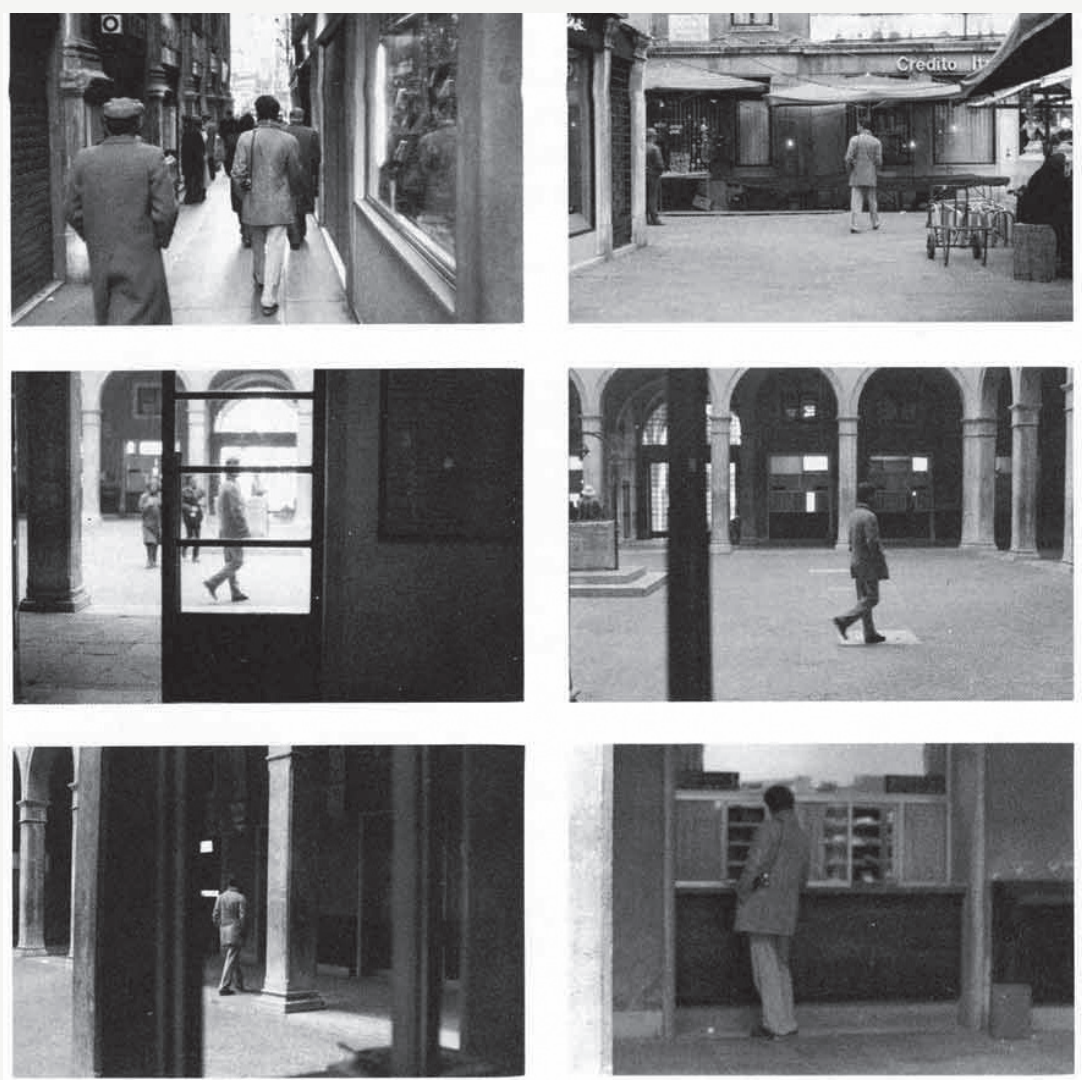

Suite Vénitienne, Sophie Calle, I98I.

A aura benjaminiana é uma aparição única, um momento, vinculado diretamente à experiência e aos sentidos. Algo está próximo espacialmente e distante temporalmente. No mundo moderno, o instante aurático é substi- 
tuído por uma aproximação forçada com o objeto, uma vez que o indivíduo consegue, por meio das técnicas de reprodução, captar o outro (indivíduos e objetos) como um fenômeno único. Porém é essa mesma técnica que permite um novo despertar, como Sophie Calle faz com suas imagens no espectador. Mesmo distante daquele momento, há uma identificação com o instante. Perceber a aura de uma coisa para Benjamin é investi-la do poder de revidar o olhar. A presença de Henri B. toca o olhar. A experiência aurática não está restrita à estética natural; é através dela que o eu e as coisas estabelecem uma relação de despertar mútuo.

E é esse "despertar" que alterna a própria relação de Calle com seu objeto. Há o encontro entre ambos, tão almejado. Ele a vê, aproxima-se, inicia a conversa. Ele a reconhece e convida a caminhar. Ela aceita e permanece em silêncio. Por mais que a oratória dele seja recorrente durante o passeio, a ausência de linguagem falada dela não diminui o impacto da presença. Ao contrário, diz muito, e desperta na artista um sentimento de esvaziamento: ela está no fluxo do encontro, o que a faz encontrar-se em si mesma. Ao tentar registrar o reflexo (ela tenta tirar uma foto do rosto de Henri B.), ele não permite. O reflexo de si é você mesmo: "We arrive in front of the Café Florian. He says that we must part. I try to photograph him; he holds his hand up to hide his face and cries, 'No, that's against the rules'" (CALLE, I988, p.5I). 


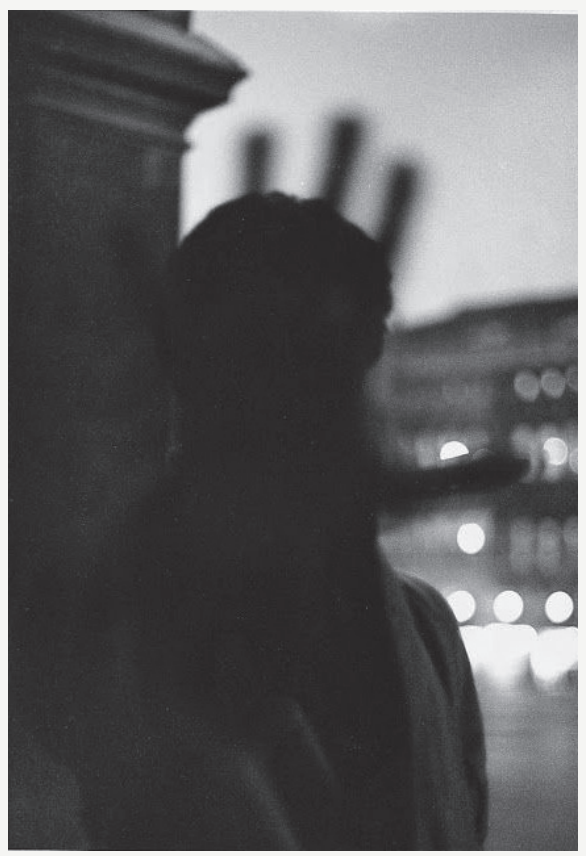

Suite Vénitienne, Sophie Calle, 1981.

O adeus é estabelecido. O rompimento amoroso transborda no ato físico: é carnaval em Veneza, cidade-armadilha, labirinto inevitável... Sophie Calle, mascarada, expurga por meio da dança, como um rito de passagem, e encontra um arlequim, commedia dell'arte, com quem escolhe passar a noite: "I return to the carnival. I dance hours on end and spend the night on a bench with a harlequin. / At day break, I leave while he sleeps. Nobody is on the streets. Alone, I wander back over the routes we took together these last two days, Henri B. And I".(CALLE, I988, p.5I). 


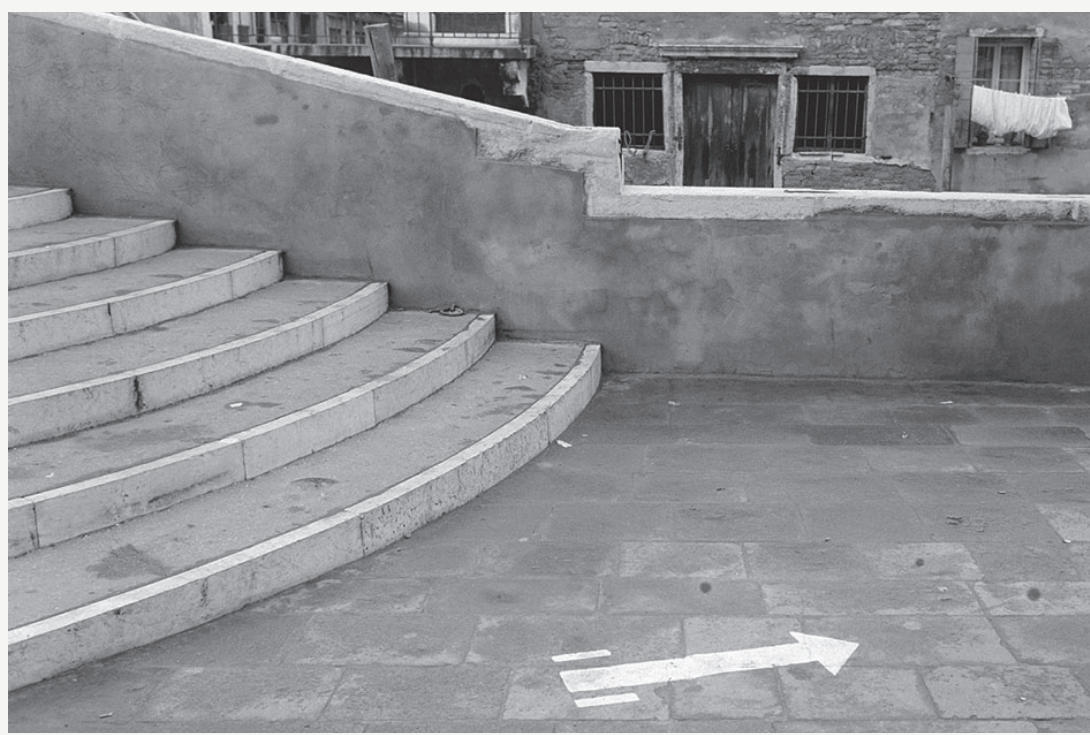

Suite Vénitienne, Sophie Calle, I98I.

"When you are unmasked, everything is there. And indeed the game stops there (...) when he recognizes her" (BAUDRILLARD, I988, p.85). Nada é mais difícil do que retornar, nua, à existência. Sophie Calle despede-se de Henri B. no retorno a Paris, com um adeus distante, um último registro. Deus existe, oro por ele. Deus existe, encontrei-me cara a cara com ele. Há uma diferença abrupta entre as frases. Havia um momento delicado no final de cada dia, antes do encontro real, em que Calle, no calor da batalha, abandonava a posição de detetive, pois ela sabia que, no amanhã (e no outro dia), continuaria a buscar a paixão, pois Veneza é cíclica, o tempo é cíclico e, consequentemente, a vida. Como a oração diária. Isto é aura, perdida no contato com o real, com o encontro casual com o objeto, com sua reprodutibilidade através de meras fotografias. Não mais imagens; fotografias comuns.

"Everything is at the vanishing point" (BAUDRILLARD, I988, p.85). Aura como a face da obra de arte constituída e transmitida na tradição, 
na narrativa, que acena para nós de seu instante derradeiro. Aura como uma forma humana de relação, uma capacidade de experienciar o mundo por meio de uma intersubjetividade em que até as coisas são investidas da possibilidade de revidar o olhar. Aura como uma possível relação histórica com objetos sensíveis, para além das condições de produção do capital.

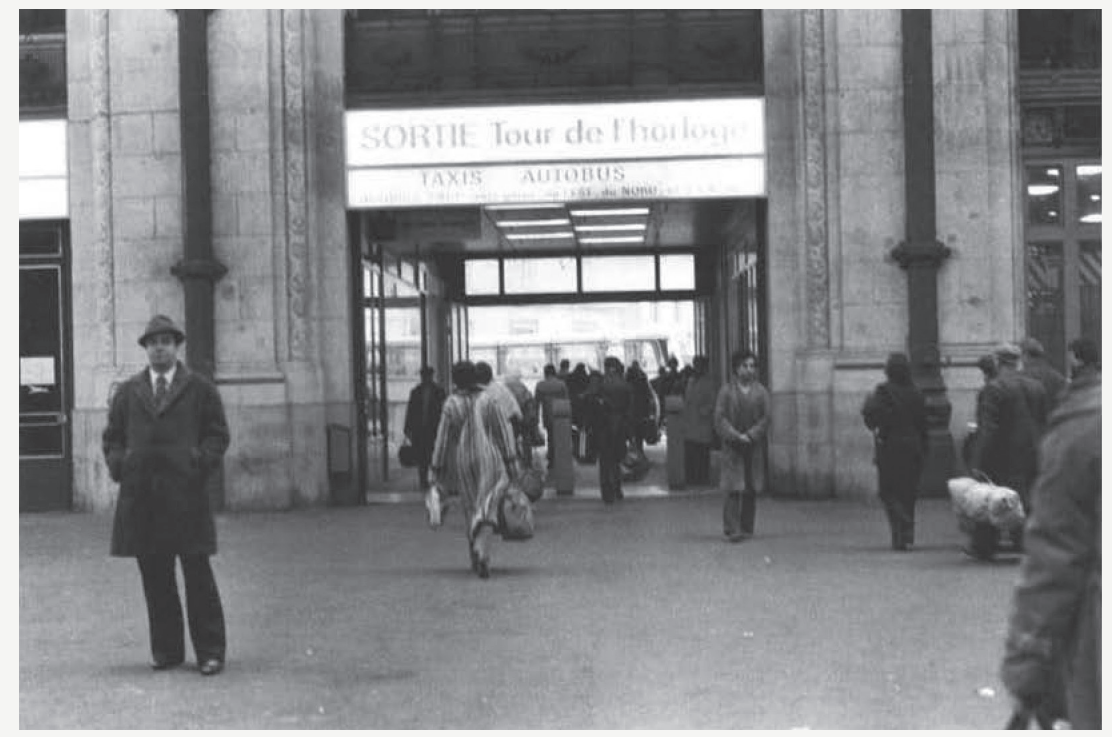

Suite Vénitienne, Sophie Calle, I98I.

No fundo: por que ele, por que Veneza, por que persegui-lo? Todos esses elementos estabelecem um ponto de fuga da realidade material, cotidiana, vazia e linear que vivemos. Veneza e Paris, cidades-palco dos deslocamentos de Sophie Calle, são labirintos arquitetônicos onde os cruzamentos são recorrentes. Não são cidades lineares, racionais, como Nova York, por exemplo. Há uma mistura de promiscuidade e discrição numa relação dual com o espaço potencializado pelas máscaras (do carnaval veneziano), pelas calles, pelo detetivesco, pelo desejo, pelo fugaz. Pontos de 
fuga. O casaco de Henri B. também é uma fuga: é para ele que a lente olha. Segui-lo protege a identidade do outro. Calle também se utiliza do casaco para esconder-se, refugiar-se, manter sua identidade. O casaco é um casulo, é o casco. Se observamos as fotos, encontraremos pontos de fuga em quase todas as imagens: corredores, claro/escuro, janelas, olhares de esguio para a intimidade.

O fotógrafo, por si só, é mestre na arte da fuga, do desaparecimento: atrás das lentes, preserva sua face diante de seu reflexo. Henri B., ou outro qualquer, não é mais objeto de desejo. Evapora dentro da multidão. Como o gozo, psiquicamente: ao mesmo tempo, como a experiência intersubjetiva do prazer e da fuga do prazer e da sedução e da fuga da sedução. O depois, o vazio. Fragmentos do real como um grande mosaico das experiências/vivências. Narrativas do eu enquanto ausente de si. Please, follow me. 


\section{REFERÊNCIAS}

BAUDELAIRE, C. As flores do mal. Edição bilíngue. Trad. Ivan Junqueira. Rio de Janeiro: Nova Fronteira, I985.

BAUDRILLARD, J. Please follow me. In: CALLE, S. Suite Vénitienne. Paris: Éditions de l’Étoile - Cathiers du cinema 9 passage de la Boule Blanche, I988, p.75-87.

BENJAMIN, W. Obras escolhidas - Volume r. Magia e técnica, arte e política: ensaios sobre literatura e história da cultura. 3. ed. São Paulo: Editora Brasilense, I987.

BURGER, P. Teoria da vanguarda. São Paulo: Cosac Naify, 2008.

CAIMI, C. L.; OLIVEIRA, R. P. de (Orgs). Sobre alguns temas em Walter Benjamin. Porto Alegre: Editora UniRitter, 2015.

CAlle, S. Mas-tu vue Paris. Paris: Center Georges Pompidou/Édition Xavier, 20o3. Suite Vénitienne. Paris: Éditions de l'Étoile - Cahiers du cinema 9 passage de la Boule Blanche, I988.

DUBOIS, P. Cinema, vídeo, Godard. Trad. Mateus Araújo Silva. São Paulo: Cosac Naify, 2004 .

PALHARES, T. H. P. Aura: a crise da arte em Walter Benjamin. I. ed. São Paulo: Editora Barracuda, 2006. 